hybrids between the common pheasant and Reeves's pheasant, according as to whether the first or second species was the male parent, and vice versa, is recorded by $\mathrm{Mr}$. J. C. Phillips, in The American Naturalist for November, I9I3. So different, indeed, are these two types of hybrids, that they might well be regarded as distinct species. In the cross with the Reeves as male parent that species impressed its characters much more strongly on the hybrids than was the case with the opposice cross. As the progeny of such a cross are generally sterile, the crossing could not be further continued.

The biological survey division of the U.S. Department of Agriculture has issued, as Bulletin No. 43, a useful list of literature relating to the food of birds published by the members of the survey between the years 1885 and I9II. Also, as Circulars Nos. 92 and 93, proposed regulations for the protection of migratory birds, with a popular explanation of their scope and probable effect. The scheme includes uniformity in protection of migratory game and insectivorous birds in the several States; protection of birds in spring, while en route to their nesting grounds and while mating; uniformity in protection of migratory birds at night; establishment of protected migration routes along three great rivers in the central United States; complete protection for five years for the smaller shore-birds and species which have been greatly reduced in numbers; and reduction of the open season on migratory game-birds, to the extent, in most cases, of not more than from 25 to 50 per cent.

In Nos. 2 and 3 (issued together) of the Austral Avian Record, Mr. G. M. Mathews proposes no fewer than twenty-one new generic names for Australasian birds, in addition to certain others to replace inadmissible ones. In this "splitting" are included the genera Sula, hitherto taken to comprise all the gannets, and Phæthon, the accepted term for all the tropic-birds. Other species and races are named in No. 4 of the same volume.

Under the somewhat too generalised title of "Notes upon Some Rare New Zealand Birds," Mr. Symington Grieve communicates to vol. xix., No. 4, of the Proceedings of the Royal Physical Society of Edinburgh, an important article on the history, habits, distribution, and distinctive characters of the various species of Apteryx. Most of these birds are now very scarce, and it is believed that $A$. haasti has either been already exterminated, or is on the verge of extinction. The author alludes to all the species under the name of "kiwi," but, we believe, the Maoris restrict that title to certain species, designating the others "rowa."

To the number of The Emu for October, I9I3, Mr. A. J. Campbell communicates an account, illustrated by three beautifully coloured plates, of an unrivalled collection of Australian birds'-eggs, brought together by Mr. H. L. White, of Beltrees, near the upper part of the Hunter River. Out of a total of between 800 and 900 species and subspecies recognised in the "Official Check-list of the Birds of Australia," Mr. White possesses the eggs of no fewer than 800 , thus lacking only about 8 per cent. of the whole. It may be added that the Beltrees Estate, comprising about 200,000 acres, is a close sanctuary for birds, where many species are increasing in number.

In a paper on fossil feathers, published in No. 7 of vol. xxi. of The Journal of Geology, Dr. R. W. Shufeldt states that several specimens described as such have subsequently proved to be ferns. The authors figure a number of specimens or more or less well-marked impressions of feathers, from those of Archæopteryx upwards.

R. L.

\section{THE INDIAN MUSEUM AND SCIENCE CONGRESS.}

CALCUTTA was the scene last month of a celebration of considerable importance to all who are interested in the progress of science in the East. The trustees of the Indian Museum resolved to commemorate in a fitting manner the centenary of the premier museum in Asia, and a short account of its proceedings will no doubt be of interest to those who were not privileged to take part in them.

The celebrations happily coincided in time with the first Indian Science Congress, the meetings of which were appropriately held in the rooms of the Asiatic Society on January $15^{-17}$.

At the opening meeting of the congress, the Hon. Justice Sir Asutosh Mukerji presided. Sir A. Mukerji, in his opening address, said that more than two years ago Prof. MacMahon, of Canning College, Lucknow, and Prof. Simonsen, of the Presidency College, Madras, brought forward a proposal for the foundation of an Indian Association for the Advancement of Science. The object and scope of the proposed institution were stated to be similar to those of the British Association, namely, to give a stronger impulse and a more systematic direction to scientific inquiry, to promote the intercourse of societies and individuals interested in science in different parts of the country, to obtain a more general attention to the objects of pure and applied science, and the removal of any disadvantages of a public kind which may impede its progress. The proposal was widely circulated, and met with a favourable reception. It was felt by many men of experience that the pressure of heavy official duties, the climatic conditions which prevail in the country, and the long distances which have to be traversed, constitute practical difficulties in the immediate formation of a peripatetic association designed to meet periodically in turn in all the different centres of scientific activity. The call to scientific workers met with a generous response, as was amply indicated by the presence at the congress of many notable investigators from all parts of the Indian Empire.

The reading of papers commenced at the conclusion of the address, and in the course of the congress a number of important communications were made in various departments of science. The chairmen of the various sections were :-Chemistry, Prof. P. S. MacMahon; Physics, Prof. V. H. jackson; Zoology, Dr. J. R. Henderson; Geology, Dr. H. H. Hayden; Botany, Mr. C. C. Calder; Ethnography, Mr. L. K. Anantha Krishna Iyer. Mr. D. Hooper, of the Indian Museum, was honorary secretary and treasurer of the congress.

The centenary celebrations of the Indian Museum commenced on the afternoon of January ${ }^{5} 5$, by a reception of delegates at the rooms of the Asiatic Society. His Excellency Lord Carmichael, Governor of Bengal, who took a keen interest both in the museum celebrations and in the congress, was present as chairman of the centenary committee, and took the chief part in receiving the delegates.

The Indian Museum owes its inception to the Asiatic Society of Bengal, which was founded by Sir William Jones in 1784 . Donations of various kinds having gradually accumulated in the society's premises, Dr. N. Wallich, the Danish botanist of Serampore, wrote, on February 2, I8I4, a letter to the society strongly advocating the formation of a museum. This proposal was forthwith accepted. The scope of the museum was defined in the widest terms, and contributions throwing light on the history or science of the East were solicited. The museum thus inaugurated made rapid progress, and the specimens brought to- 
sether were housed until 1875 in the rooms still occupied by the Asiatic Society of Bengal. In 1875 the collections were transferred by the society to the fine building which had been erected for their reception on Chowringhee, the main thoroughfare of Calcutta. Since then, through the labours of distinguished superintendents, viz., Dr. John Anderson, Mr. J. Wood-Mason, Lieut.-Col. A. Alcock, and Dr. N. Annandale, progress has been rapid and continuous. Considerable extensions to the original building have been found necessarv, and, thanks to the unrivalled Oriental collections and to a very complete library, the museum is not only a great educational institution, but also an important centre for research, especially in zoology and geology.

The celebrations terminated in a very successful conversazione held in the Indian Museum on January I7. The company present included their Excellencies Lord and Lady Carmichael, and a representative selection of the European and Indian communities of Calcutta, as well as the delegates and the members of the Science Congress. An extremely interesting series of exhibits had been arranged by the officers of the museum, comprising archæological, art, botanical, ethnological, geological, and zoological specimens, and brief reference may be made to some of the more important of these.

Prominent among the archæological exhibits was one to illustrate the evolution of the Buddha image, commencing with the Gandhara or Indo-Greek school, and continuing with the later types from Mathura, Amarawati, Sarnath, Bengal, Tibet, and Further India, The botany and ethnology of the Abor country, visited by a punitive expedition in I9II-I2, were illustrated by specimens exhibited by Messrs. Hooper, Kemp, and Coggin Brown. The geological series lent by the Geological Survey of India comprised characteristic Indian fossils exhibited by Dr. G. E. Pilgrim.

The zoological exhibits, which were very numerous, attracted a large share of attention. Prominent among them was a series of deep-sea animals dredged by the R.I.M.S. Investigator, exhibited by Major Lloyd and Captains Seymour Sewell and T. L. Bomford, and comprising fish, crustacea, mollusca, echinoderms, and corals. Remarkable fresh-water invertebrates recently discovered in India were exhibited by Dr. Annandale and Messrs. Kemp, Gravely, and Agharlkar, and included the very interesting medusa (Limnocnida indica), discovered three years ago in the upper waters of the River Kistna in the Western Ghats. Recently discovered Indian fresh-water fishes and specimens of the fresh-water sting-rays of the Ganges were shown by Dr. Chaudhuri. Dr. Annandale exhibited a series of specimens to illustrate a paper which he read before the Science Congress on convergence in aquatic animals. Convergence in skeletal structure was shown between different fresh-water sponges, and in the special form of spicules in different families of sponges, while the same phenomenon was also illustrated in the degeneracy of calcareous plates in the stalked barnacles, in the form of shell between the marine oysters and the fresh-water family Aetheriidæ, in degeneration of the eyes in the Indian electric rays, in the independent evolution of pigmentation of the ventral surface in different deep-sea rays, in general form between certain carp of the Himalayas and Tibet and the Salmonidæ, and in the independent evolution of adhesive suckers in different tadpoles and fishes inhabiting rapid-running streams. Mr. Kemp exhibited zoological specimens from the Abor country, the expedition to which he accompanied in the capacity of naturalist, among them being the Peripatus (Typhloperipatus williamsoni), which he discovered, the first representative of the group to be met with north of the Isthmus of Kra in the Malay Peninsula. A small but interesting collection of type-specimens of Asiatic squirrels containing the type of Funambulus layardi, Blyth, mounted in the Asiatic Society's Museum seventy years ago, was exhibited to prove that it is possible to preserve mammal skins in Calcutta for an indefinite period, if proper precautions are taken.

\section{UNIVERSITY AND EDUCATIONAL \\ INTELLIGENCE.}

Birmingham.-The trustees of the John Feeney bequest have granted to the University the sum of roool. in aid of research and instruction in wireless telegraphy. The money is to be applied to the erection of a wireless telegraphic installation on the University buildings at Edgbaston.

CAMBridge.-Dr. Hobson, Sadleirian professor of pure mathematics, has been nominated to represent the University on the occasion of the celebration on June $29-30$ and July I of the three hundredth anniversary of the foundation of the University of Groningen.

The Vice-Chancellor announces that Mrs. A. M. Babington has expressed the wish to defray the cost of the gallery which is being built to house the exhibit of local antiquities. This gallery, which will be known as the "Babington Gallery," is being erected to the memory of the donor's husband, Prof. Babington, of St. John's College, and professor of botany in the University. It was Prof. Babington who, in the early forties of last century, initiated the Cambridge Antiquarian Museum, which forty years afterwards ceded to the University. The extent of Mrs. Babington's benefaction will amount to $\times 55 \mathrm{ol}$.

The University Buildings Syndicate has had under consideration the question of providing a central electric power station to supply the numerous science and other buildings on either side of Downing Street. At the present moment there is an assortment of engines supplying these various laboratories, but the system has many inconveniences, and is costly and extravagant. The syndicate wishes to be authorised to expend a sum not exceeding $3000 l$. in providing a power station in connection with the engineering laboratory, and also to enter into a contract with the Cambridge Electric Supply Company for the supply of electricity for a period of ten years.

The next combined examination for fifty-three entrance scholarships and a large number of exhibitions, at Pembroke, Gonville and Caius, Jesus, Christ's, St. John's, and Emmanuel Colleges, will be held on Tuesday, December r, I9I4, and following days. Mathematics, classics, natural sciences, and history will be the subjects of examination at all the above-mentioned colleges. Most of the colleges allow candidates who intend to study mechanical science to compete for scholarships and exhibitions by taking the papers set in mathematics and natural sciences. Forms of application for admission to the examination at the respective colleges may be obtained from the masters of the several colleges, from any of whom further information respecting the scholarships and exhibitions and other matters connected with the colleges may be obtained.

Mr. S. Hey, secretary to the Education Committee of Newcastle-upon-Tyne, has been appointed director of education for Manchester in succession to the late Mr. C. H. Wyatt.

IT is announced in Science of February I $_{3}$ that Bowdoin College has received a bequest of roo,oool. for the general fund of the college from the estate of the late Mr. Edwin B. Smith, former assistant attorney-general of the United States, who died in New York on January 5. It is stated in the same issue of our contemporary that, through the will of the

$$
\text { No. } \left.23 \text { I3, VOL. } 5^{2}\right]
$$

